PATIK : Jurnal Hukum

https://ejournal.uhn.ac.id/index.php/patik

Volume 10 Nomor 01 April 2021 Page : 25 - 37

p-issn : 2086 - 4434

\title{
PERANAN KEPOLISIAN DALAM MENANGGULANGI PENYALAHGUNAAN NARKOTIKA YANG DILAKUKAN OLEH ANAK DI BAWAH UMUR (STUDI DI KEPOLISIAN RESORT SIMALUNGUN)
}

\author{
Andrew Simon Petrus Siburian, Rinsofat Naibaho, Kasman Siburian \\ Fakultas Hukum, Universitas HKBP Nommensen \\ rinsofatnaibaho@uhn.ac.id
}

\begin{abstract}
Abstrak
Pada dasarnya narkotika sangat diperlukan dan mempunyai manfaat dibidang kesehatan dan ilmu pengetahuan, akan tetapi penggunaan narkotika menjadi berbahaya jika terjadi penyalahgunaan atau tidak sesuai dengan standart pengobatan. Kepolisian yang diberikan kewenangan untuk melakukan pencegahan dan pemberantasan tindak pidana dan menjadi ujung tombak dalam posisi awal pelaksanaan sistem peradilan wajib melakukan tugas dan wewenang sebagai penegak hukum. Hal tersebut menjadi tantangan bagi aparat polri untuk menanggulangi dan membasmi peredaran narkotika yang sudah menyerang keseluruh kalangan umur. Permasalahan dalam skripsi ini adalah mengenai Peranan Kepolisian Dalam Menanggulangi Penyalahgunaan Narkotika Yang Dilakukan Oleh Anak Di Bawah Umur Studi di Kepolisian Resort Simalungun. Metode penelitian yang digunakan adalah metode wawancara dan metode studi kepustakaan yaitu pengumpulan data yang dilakukan berdasarkan peratuan perundang-undangan, buku-buku yang ada kaitannya dengan masalah yang diteliti. Berdasarkan hasil penelitian dipahami bahwa upaya dan hambatan kepolisian dalam menanggulangi penyalahgunaan narkotika yang dilakukan oleh anak dibawah umur di wilayah kepolisian resort simalungun yaitu dengan upaya represif dan preventif.
\end{abstract}

Kata Kunci: Anak Di Bawah Umur, Peranan Kepolisian, Penyalahgunaan Narkotika, Tindak Pidana

\begin{abstract}
Basically narcotics is very necessary and has benefits in the field of health and science, however the use of narcotics becomes dangerous if there is abuse or does not comply with standard treatment. The police, which are given the authority to carry out the prevention and eradication of criminal acts and become the spearhead in the initial position of implementing the judicial system, are obliged to carry out their duties and powers as law enforcers. This is a challenge for the police apparatus to tackle and eradicate the circulation of narcotics that have attacked all ages. The problem in this thesis is regarding the Role of the Police in Tackling Narcotics Abuse by Underage Children at the Simalungun Resort Police. The research method used is the interview method and the literature study method, namely data collection which is carried out based on statutory regulations, books that are related to the problem under study. Based on the results of the study, it is understood that the efforts and obstacles of the police in overcoming narcotics abuse by minors in the Simalungun resort police area are through repressive and preventive measures.
\end{abstract}

Keywords: Minors, Role of Police, Narcotics Abuse, Crime 


\section{Pendahuluan}

Dalam pasal 1 ayat (3) undang-undang Negara Republik Indonesia Tahun 1945 menyatakan "Indonesia adalah Negara Hukum". Hal inilah yang menjadi landasan filosofis Negara Indonesia dalam menerapkan peraturan perundang-undangan. Semakin kuatnya dasar hukum serta menjadi amanat Negara dilihat dari masuknya ketentuan ini kedalam bagian pasal UUD RI 1945. Berdasarkan hal-hal tersebut sehingga dengan demikian dapat dikatakan bahwa Indonesia adalah Negara yang bertujuan menyelenggarakan ketertiban hukum serta mewujudkan kesejahteraan umum, membentuk suatu masyarakat yang adil dan makmur. ${ }^{1}$

Latar belakang lainnya undang-undang narkotika dalam pembangunan kesehatan diarahkan guna tercapainya kesadaran, kemauan, dan kemampuan untuk hidup sehat bagi setiap masyarakat agar dapat mewujudkan derajat kesehatan yang optimal, sedangkan lahirnya undang-undang system peradilan pidana anak dihadapkan dapat mengisi ruang keadilan sehingga anak tetap bermartabat.

Kurangnya edukasi dan penyuluhan tentang narkotika yang tidak merata membuat banyak anak dibawah umur yang terjerumus dan menggunakan narkotika tanpa sepengetahuan orangtuanya. Penyalahgunaan narkotika yang dilakukan oleh anak dibawah umur sudah sulit dikendalikan karena terlalu banyak anak yang sudah menggunakan narkotika dimasa sekarang ini. Anak yang seharusnya menjadi generasi penerus bangsa dimasa yang akan datang. Anak-anak memerlukan bimbingan yang khusus karena pada umumnya anak memiliki rasa keingintahuan yang sangat besar, sehingga sesuatu hal yang baru dapat mengarah pada kebaikan atau juga sebaliknya.

Usia anak yang menggunakan narkotika sangat bervariasi, bahkan untuk sekarang ini anak sekolah dasar sudah banyak yang menghisap rokok sehingga sudah merasakan zat adiktif yang ada didalam rokok tersebut. Zat adiktif "zat yang menyebabkan efek kecanduan" yang terdapat dalam tembakaunya. Pada awalnya anak menghisap rokok, dan kebiasaaan inilah, yang meyebabkan pergaulan anak pun mulai jauh dari yang seharusnya, terlebih lagi anak tersebut bergabung dalam lingkungan orang dewasa yang menggunakan narkotika, yang awalnya saja mencoba lalu ketergantungan. Berikut dapat dilihat pada tabel dibawah ini anak dibawah umur yang terlibat penyalahgunaan narkotika yang diamankan Kepolisian Resort Simalungun dalam kurun waktu tahun 2018-2020.

Tabel 1.

Penyalahgunaan Narkotika yang dilakukan oleh anak dibawah umur daerah Polres Simalungun tahun 2018-2020

\begin{tabular}{|c|c|c|c|c|c|}
\hline \multirow{2}{*}{ Tahun } & \multicolumn{5}{|c|}{ Jenis } \\
\cline { 2 - 6 } & Shabu & Ganja & Estasy & Heroin & Lain-lain \\
\hline $\mathbf{2 0 1 8}$ & 7 & 3 & - & - & - \\
\hline $\mathbf{2 0 1 9}$ & 5 & 1 & - & - & - \\
\hline $\mathbf{2 0 2 0}$ & 4 & - & 1 & - & - \\
\hline Total & 16 & 4 & 1 & - & - \\
\hline
\end{tabular}

Berdasarkan uraian diatas, maka yang menjadi rumusan masalah adalah sebagai berikut:

1. Bagaimana upaya kepolisian dalam menanggulangi penyalahgunaan narkotika yang dilakukan oleh anak dibawah umur di wilayah Kepolisian Resort Simalungun?

${ }^{1}$ Ubaedillah dan Abdul Rozak, Pancasila, Demokrasi, HAM dan Masyarakat Madanii, Kencana, (Jakarta : 2012) hlm 121. 
2. Bagaimana hambatan kepolisian dalam menanggulangi penyalahgunaan narkotika yang dilakukan oleh anak dibawah umur di wilayah Kepolisian Resort Simalungun?

\section{Tinjauan Pustaka}

Istilah polisi, Raymond B.Fosdick, memberkan pengertian bahwa polisi sebagai kekuatan konstitusi utama untuk melindungi individu-individu dalam hak-hak hukum mereka. $^{2}$ Polisi dalam arti formal, mencakup penjelasan tentang organisasi tentang kedudukan dari pada instansi kepolisian sedangkan polisi dalam arti materil memberikan jawaban terhadap persoalan-persoalan tugas dan wewenang dalam rangka menghadapi bahaya/gangguan keamanan dan ketertiban, baik dalam rangka kewenangan kepolisian umum maupun melalui ketentuan-ketentuan yang diatur dalam peraturan (undang-undang tentang kepolisian khusus). ${ }^{3}$

Menurut Sadjijono, Istilah "polisi" dan "kepolisian" mengandung pengetian yang berbeda. Isitilah "polisi" adalah sebagai organ atau lembaga pemerintah yang ada dalam Negara, sedangkan isitilah "kepolisian" adalah sebagai organ dan sebagai fungsi. ${ }^{4}$ Istilah Kepolisian, dalam Kamus Besar Bahasa Indonesia, adalah urusan Polisi atau segala sesuatu yang bertalian dengan Polisi. ${ }^{5}$ Kepolisian Negara Republik Indonesia, selanjutnya disebut Kepolisian Negara, ialah alat Negara penegak hukum yang terutama bertugas memelihara keamanan di dalam negeri. ${ }^{6}$

Khusus dalam rangka pembangunan nasional, tugas memelihara keamanan didalam negeri ditujukan kepada tiap gangguan/bahaya yang datAng dari dalam dan yang mengancam usaha-usaha mencapai tujuan Nasional kita. Kepolisian Negara dalam menjalankan tugasnya selalu menjunjung tinggi hak-hak azasi rakyatdan hukum Negara. Dalam Pasal 13 Undang-Undang No.2 Tahun 2002 Tentang Kepolisian Negara Republik disebutkan, Tugas Pokok Kepolisian Negara Republik Indonesia adalah:

a. Memelihara Keamanan Dan Ketertiban Masyarakat;

b. Menegakkan Hukum; Dan

c. Memberikan perlindungan, pengayoman, dan pelayanan kepada masyarakat.

Mengenai tugas yang harus dilaksanakan oleh Kepolisian Negara Republik Indonesia disebutkan dalam Pasal 14 Undang-Undang No. 2 Tahun 2002 Tentang Kepolisian Negara Republik Indonesia. Dalam melaksanakan tugas pokok sebagaimana dimaksud dalam Pasal 13 Kepolisian Negara Republik Indonesia bertugas :

a. Melaksanakan Pengaturan, Penjagaan, Pengawalan, Dan Patroli Terhadap Kegiatan Masyarakat Dan Pemerintah Sesuai Kebutuhan;

b. Menyelenggarakan Segala Kegiatan Dalam Menjamin Keamanan, Ketertiban, Dan Kelancaran Lalu Lintas Di Jalan;

c. Membina Masyarakat Untuk Meningkatkan Partisipasi Masyarakat, Kesadaran Hukum Masyarakat Serta Ketaatan Warga Masyarakat Terhadap Hukum Dan Peraturan Perundang-Undangan;

d. Turut Serta Dalam Pembinaan Hukum Nasional;

e. Memelihara Ketertiban Dan Menjamin Keamanan Umum;

\footnotetext{
${ }^{2}$ H.R. Abdulssalam, Hukum Kepolisian, (Jakarta : PTIK Press, 2011), hal.7.

${ }^{3}$ Ibid. hal 8.

${ }^{4}$ H.Pudi Rahardi, Hukum Kepolisian, ( Surabaya : Laksbang Mediatama, 2007), hal 56.

${ }^{5}$ H.R. Abdulssalam .Op.Cit. hal 9.

${ }^{6}$ C.S.T. Kansil, Buku Saku Hukum (hukum untuk tiap orang), (Jakarta : Erlangga, 1986), hal 70.
} 
f. Melakukan Koordinasi, Pengawasan, Dan Pembinaan Teknis Terhadap Kepolisian Khusus, Penyidik Pegawai Negeri Sipil, Dan Bentuk-Bentuk Pengamanan Swakarsa;

g. Melakukan Penyelidikan Dan Penyidikan Terhadap Semua Tindak Pidana Sesuai Dengan Hukum Acara Pidana Dan Peraturan Perundang-Undangan Lainnya;

h. Menyelenggarakan Identifikasi Kepolisian, Kedokteran Kepolisian, Laboratorium Forensik Dan Psikologi Kepolisian Untuk Kepentingan Tugas Kepolisian; I. Melindungi Keselamatan Jiwa Raga, Harta Benda, Masyarakat, Dan Lingkungan Hidup Dari Gangguan Ketertiban Dan/Atau Bencana Termasuk Memberikan Bantuan Dan Pertolongan Dengan Menjunjung Tinggi Hak Asasi Manusia;

i. Melayani Kepentingan Warga Masyarakat Untuk Sementara Sebelum Ditangani Oleh Instansi Dan/Atau Pihak Yang Berwenang;

j. Memberikan Pelayanan Kepada Masyarakat Sesuai Dengan Kepentingannya Dalam Lingkup Tugas Kepolisian; Sertal. Melaksanakan Tugas Lain Sesuai Dengan Peraturan Perundang-Undangan.

Perkataan narkotika berasal dari bahasa Yunani, yaitu "narcois" yang berarti "narkose" atau menidurkan, yaitu suatu zat atau obat-obatan yang membiuskan sehingga tidak merasakan apa-apa. Narkotika adalah zat yang bisa menimbulkan pengaruh-pengaruh tertentu bagi mereka yang menggunakannya, berupa pembiusan, hilangnya rasa sakit, rangsangan semangat dan halusinasi atau timbulnya khayalan-khayalan. Didalam dunia medis narkotika dimanfaatkan untuk pengobatan seperti dibidang pembedahan, menghilangkan rasa sakit. ${ }^{7}$ Penggunaan narkotika dibidang kedokteran dan penelitian, pengembangan ilmu pengetahuan memang dapat dinikmati manfaatnya oleh para ilmuwan dan ahli-ahli lain yang profesional. ${ }^{8}$

Tetapi apabila penggunaan narkotika tidak diatur, dapat menibulkan efek yang negatif, yaitu kecanduan kepada si pemakai dan akibat yang ditimbulkan karena efek kecanduan, pemakai tidak segan-segan melakukan tindakan kriminal demi tercapainya keinginan untuk memakai narkotika tersebut, seperti tindak pidana pencurian, pemerkosaan, dan lain-lain. Disamping itu biasanya orang yang ketagihan suka mengabaikan makanan dan kurang memperhatikan kesehatan, karena terlalu disibukkan dengan mempersiapkan obat dan kegiatan "mengobati" dirinya. Akhirnya mengalami malnutrisi dan terkena bermacam-macam penyakit infeksi, seperti bases, keracunan darah, hepatitis bahkan AIDS atau penurunan kekebalan tubuh. ${ }^{9}$

Bahwa yang dimaksud dengan narkotika ialah candu, ganja, kokain, zat-zat yang bahan mentahnya diambil dari benda-benda tersebut, yakni morphine, heroin, codein, hasisch,cocain. Dan termasuk juga narkotika sintesis yang menghasilkan zat-zat, obat-obat yang tergolong dalam Hallucinogen dan Stimulant. ${ }^{10}$

Penggunaan istilah tindak pidana merupakan terjemahan dari istilah strafbaar feit. Akan tetapi di dalam berbagai perundang-undangan yang berlaku di indonesia tidaklah seragam. Adapun beberapa istilah-istilah yang dipergunakan dsalam bahasa Indonesia antara lain:

1. Peristiwa pidana

2. Perbuatan pidana

\footnotetext{
${ }^{7}$ Maidin Gultom, Perlindungan Hukum terhadap Anak dan Perempuan (Medan : PT Refika Aditama, 2012), Hal.121.

${ }^{8}$ Sudarsono, Kenakalan Remaja (Jakarta : PT. RINEKA CIPTA, 2018), hal. 65.

${ }^{9}$ Andi Hamzah, Kejahatan Narkotika Dan Psikotropika, (Jakarta : Sinar Grafika, 2018) hal. 5.

${ }^{10}$ Moh.Taufik Makaro, S.H., M.H. Tindak Pidana Narkotika, (Jakarta : Ghalia Indonesia, 2019)hal.
} 18. 


\section{Tindak pidana}

4. Pelanggaran pidana

Moeljatno mengatakan strafbaar feit atau perbuatan pidana adalah suatu perbuatan yang dilarang oleh suatu aturan hukum, larangan mana disertai ancaman (sanksi) yang berupa pidana tertentu, bagi setiap orang yang melanggar larangan tersebut. ${ }^{11}$

Tindak pidana narkotika diatur dalam Bab XV pasal 111 sampai dengan pasal 148 Undang-Undang Nomor 35 tahun 2009 yang merupakan ketentuan khusus, walaupun tidak disebutkan dengan tegas dalam Undang-Undang Narkotika bahwa tindak pidana yang diatur didalamnya adalah tindak kejahatan. Alasannya, kalau narkotika hanya untuk pengobatan dan kepentingan ilmu pengetahuan, maka apabila ada perbuatan diluar kepentingan-kepentingan tersebut sudah merupakan kejahatan mengingat besarnya akibat yang ditimbulkan dari pemakaian narkotika secara tidak sah sangat membahayakan bagi jiwa manusia. $^{12}$

Penggunaan narkotika secara ilegal hanya bagi kepentingan-kepentingan pengobatan atau tujuan ilmu pengetahuan. Menteri kesehatan dapat memberi ijin lembaga ilmu pengetahuan dan atau lembaga pendidikan untuk membeli atau menanam, menyimpan untuk memiliki atau untuk persediaan ataupun menguasai tanaman papaver,koka dan ganja. ${ }^{13}$ Dalam Undang-Undang Nomor 35 Tahun 2009 Tentang Narkotika.Untuk pelaku penyalahgunaan Narkotika dapat dikenakan Undangundang No. 35 tahun 2009 tentang Narkotika, hal ini dapat diklasifikasikan sebagai berikut : ${ }^{14}$

1. Sebagai pengguna Dikenakan ketentuan pidana berdasarkan pasal 116 Undangundang Nomor 35 tahun 2009 tentang Narkotika, dengan ancaman hukuman paling lama 15 tahun.

2. Sebagai pengedar Dikenakan ketentuan pidana berdasarkan pasal 81 dan 82 Undang-undang No. 35 tahun 2009 tentang narkotika, dengan ancaman hukuman paling lama $15+$ denda.

3. Sebagai produsen 46 Dikenakan ketentuan pidana berdasarkan pasal 113 Undangundang No. 35 tahun 2009, dengan ancaman hukuman paling lama 15 tahun/ seumur hidup/ mati + denda.

Anak merupakan generasi penerus bangsa dan penerus perjuangan pembangunan yang ada. Anak adalah amanah sekaligus karunia Tuhan Yang Maha Esa yang senantiasa harus kita jaga yang dalam dirinya karena melekat harkat, martabat dan hak-hak anak sebagai manusia yang harus dijunjung tinggi. Hak asasi anak merupakan bagian dari hak asasi manusia yang termuat dalam UUD 1945 dan konvensi Perserikatan Bangsa-Bangsa dan Hak-Hak Anak. Anak adalah masa depan bangsa dan generasi penerus cita-cita bangsa, sehingga setiap anak yang berhak atas kelangsungan hidup, tumbuh, dan berkembang, berpartisipasi serta berhak atas perlindungan dari tindak kekerasan dan diskriminasi serta hak sipil dan kebebasan. ${ }^{15}$

Upaya-upaya perlindungan anak harus telah dimulai sedini mungkin, agar kelak dapat berpartisipasi secara optimal bagi pembangunan bangsa dan negara. Dalam pasal 2 ayat (3) dan (4) Undang-Undang Nomor 4 tahun 1979 tentang Kesejahteraan Anak,

\footnotetext{
${ }^{11}$ Moeljatno, Pokok-Pokok Hukum Penitensier Indonesia. (Bandung : Alfabeta,2010), hal. 9.

${ }^{12}$ Gatot Supramono, Hukum Narkotika Indonesia (Jakarta : Djambatan,2001) hal. 77.

${ }^{13}$ Soedjono Dirjosisworo, Hukum Narkotika di Indonesia (Bandung : PT.citra Aditya bakti,1990) hal. 82 .

${ }^{14}$ Sumarno Ma'asum, Penanggulangan Bahaya Narkotika dan Ketergantungan Obat (Jakarta: CV. Mas Agung, 1987), hal. 18.

${ }^{15}$ Angger Sigit Pramukti, Sistem Peradilan Pidana Anak, (Yogyakarta : Medpress, 2014), hal. 5.
} 
ditentukan bahwa: "Anak berhak atas pemeliharaan dan perlindungan baik semasa kandungan maupun sesudah dilahirkan. ${ }^{16}$

\section{Metode}

Jenis penelitian yang digunakan adalah penelitian Hukum Empiris (sosiologis) yang bersifat deskriptif (menggambarkan) dan tidak bermaksud menguji hipotesa. Penelitian Hukum Empiris adalah suatu metode penelitian hukum yang menggunakan fakta-fakta empiris yang diambil dari perilaku manusia, baik perilaku verbal yang didapat dari wawancara maupun perilaku nyata yang dilakukan melalui pengamatan langsung. Bahan Hukum yang dilakukan dalam penelitian ini adalah secara kualitatif yaitu penelitian yang mengacu pada norma hukum yang terdapat pada peraturan perundang-undangan dan studi kasus yaitu tentang peranan kepolisian dalam menanggulangi tindak pidana narkotika yang digunakan oleh anak dibawah umur. Kemudian dilakukan pembahasan dan penafsiran yang ada dan pada akhirnya dapat ditarik kesimpulan tentang masalah-masalah yang diteliti

\section{Pembahasan Dan Hasil}

Narkotika dikalangan masyarakat yang sering disalahgunakan sebagai alat pemuas diri merupakan tindak kejahatan yang tergolong sebagai kejahatan luar biasa (extraordinary crime), barang tersebut dapat ditemukan di setiap wilayah yang ada di Indonesia karena peredarannya terlalu luas dikalangan masyarakat sehingga sangat mudah bagi seorang pemakai narkotika untuk memakainya. Begitu juga kasus tindak pidana penyalahgunaan narkotika yang dilakukan oleh anak dibawah umur di wilayah Kepolisian Resort Simalungun terjadi karena kurangnya pengarahan yang dilakukan oleh orangtua untuk anaknya dan karena terlalu bebasnya pergaulan yang dilakukan. Padahal seorang anak harusnya mengetahui bahwa narkotika itu dilarang dan dapat menimbulkan efek ketagihan untuk dirinya sendiri. ${ }^{17}$

Maraknya tindak pidana penyalahgunaan narkotika yang dilakukan oleh anak dibawah umur di wilayah Polres Simalungun dari data 3 (tiga) tahun terakhir mulai tahun 2018 s.d 2020 menurut hasil data dari hasil wawancara yang dilakukan oleh penulis, maka dapat dilihat pada table dibawah ini:

Tabel 2.

Penyalahgunaan Narkotika Yang Dilakukan Oleh Anak Dibawah Umur Daerah Polres Simalungun Tahun 2018-2020

\begin{tabular}{|c|c|c|c|c|c|}
\hline \multirow{2}{*}{ Tahun } & \multicolumn{5}{|c|}{ Jenis } \\
\cline { 2 - 6 } & Shabu & Ganja & Estasy & Heroin & Lain-lain \\
\hline $\mathbf{2 0 1 8}$ & 7 & 3 & - & - & - \\
\hline $\mathbf{2 0 1 9}$ & 5 & 1 & - & - & - \\
\hline $\mathbf{2 0 2 0}$ & 4 & - & 1 & - & - \\
\hline Total & 16 & 4 & 1 & - & - \\
\hline
\end{tabular}

Sumber : Unit SAT Narkoba Polres Simalungun

\footnotetext{
${ }^{16}$ Undang-Undang Nomor 4 Tahun 1979 Tentang Kesejahteraan Anak

${ }^{17}$ Hasil wawancara dengan Bapak IPDA Bismar Saragih S.H., KBO SAT NARKOBA POLRES SIMALUNGUN, Pada tanggal 6 Agustus 2020, Pukul 11.00 wib.

${ }^{18}$ Diperoleh dari Unit NARKOBA Polres Simalungun
} 
Berdasarkan data diatas kasus tindak pidana penyalahgunaan narkotika yang dilakukan oleh anak dibawah umur mulai dari tahun 2018 s.d 2020 sangat beragam. Aiptu Ibrahim Sembiring mengatakan kasus penyalahgunaan narkotika yang dilakukan oleh anak dibawah umur di wilayah Polres Simalungun sangat memprihatinkan karena anak yang merupakan generasi Bangsa sudah melakukan tindak pidana di usia dini dan akibat yang dilakukan oleh anak tersebut dapat membuat rusak mental dan masa depannya sendiri, maka dari itu SAT NARKOBA Polres Simalungun terus melakukan penyuluhan tentang bahaya narkotika terhadap kesehatan dan mental seseorang. ${ }^{19}$

Berdasarkan kasus diatas Pasal-pasal yang digunakan dalam kasus tindak pidana penyalahgunaan narkotika yang dilakukan oleh anak dibawah umur di Unit SAT Narkoba Polres Simalungun tahun 2018 s.d 2020. Hasil wawancara dengan penyidik UNIT SAT NARKOBA POLRES SIMALUNGUN mengenai pasal pasal yang berkaitan dengan kasus tindak pidana penyalahgunaan narkotika yang dilakukan oleh anak dibawah umur yang ditangani oleh penyidik Unit SAT NARKOBA yang ditangani selama tahun 2018 s.d 2020. Di dalam hasil wawancara apabila laporan yang diterima secara resmi berbentuk laporan polisi ataupun adanya laporan masyarakat yang resah akibat seringnya terjadi transaksi narkotika di wilayah hukum Polres Simalungun maka penyidik Unit SAT NARKOBA akan memuat pasal bagi tersangka 2 Undang-Undang yaitu:

1. Pasal 112 ayat (2) dan Pasal 114 ayat (2) UU No 35 tahun 2009 tentang peyalahgunaan narkotika

2. Undang-Undang No 11 tahun 2012 tentang sistem peradilan anak sebelum memuat pasal pasal dalam Undang-undang yang berkaitan dengan kasus

Dari kasus kasus diatas, adapun kasus tindak pidana penyalahgunaan narkotika yang dilakukan anak dibawah umur yang pernah di tangani oleh penyidik Unit SAT Narkoba Polres Simalungun dari tahun 2018 s.d 2020 yaitu : Kasus yang pernah di tangani oleh Brigadir Samuel Purba tahun 2020 dan pelaku dikenakan pasal 114 ayat 2, dimana pada hari selasa tanggal 11 februari 2020 sekira pukul 14.00 wib, personil SAT narkoba Polres Simalungun mendapat informasi dari masyarakat bahwa di huta 1 marihat bandar batu VI, nagori. Marihat bandar kec bandar kabupaten Simalungun sering terjadi penyalahgunaan narkotika. Selanjutnya personil SAT Narkoba menuju lokasi tersebut dan sekira pukul 17.00 wib dilokasi biliard melihat seorang laki-laki yang ciri-ciri nya sesuai dengan yang disebutkan, personil SAT Narkoba mengamankan laki-laki tersebut dan ditemukan 1 unit hp merek vivo. Setelah interogasi laki-laki tersebut mengaku bernama Rizky Ananda alias Godok dan menerangkannya bahwa ia memiliki/menyimpan narkotika didalam rumahnya di huta I marihat bandar batu VI nagori marihat bandar kecamatan bandar kabupaten simalungun. Selanjutnya personil SAT Narkoba membawa pelaku ke lokasi tersebut serta dilakukan penggeledahan dan ditemukan barang bukti dari bawah lipatan baju di dalam kamar, ditemukan barang bukti narkotika berupa shabu, ganja dan ekstasi dan benda lainnya yang berhubungan dengan narkotika. Selanjutnya tersangka dan barang bukti diamankan ke kantor SAT Narkoba Polres Simalungun untuk proses penyidikan lebih lanjut.

Dengan pedoman barang bukti tersebut Brigadir Samuel Purba menetapkan bahwa Rizky Ananda alias Godok benar menyimpan narkotika dan ditetapkan sebagai tersangka dengan kasus kepemilikan narkotika jenis shabu, ganja dan ekstasi dengan mengenakan pasal 114 ayat 2 Undang-Undang No 35 tahun 2009 tentang narkotika. Tahapan dalam menangani laporan kasus tindak pidana penyalahgunaan narkotika yang dilakukan oleh anak dibawah umur di Unit SAT Narkoba Polres Simalungun adalah apabila ada laporan

${ }^{19}$ Hasil wawancara dengan Bapak AIPTU Ibrahim Sembiring, KAUR MINTU SAT NARKOBA POLRES SIMALUNGUN, pada tanggal 6 Agustus 2020, Pukul 11.00 wib. 
masyarakat tentang peredaran narkotika yang dilakukan oleh anak dibawah umur di suatu lokasi di wilayah hukum Polres Simalungun dan juga adanya informasi dari orang yang dapat dipercaya untuk memberitahukan bahwa akan ada transaksi narkotika yang akan dilakaukan dalam waktu tertentu. Dalam penanganannya langsung terjun kelokasi tempat dimana anak yang akan melakukan transaksi narkotika di tangkap dan apabila ditemukan narkotika maka anak tersebut akan dibawa ke Polres untuk dilakukan penyidikan lebih lanjut.

Dari hasil wawancara dengan AIPTU Ibrahim Sembiring dan BRIPTU Samuel Purba ada beberapa faktor penyebab terjadinya tindak pidana penyalahgunan narkotika yang dilakukan oleh anak dibawah umur di wilayah POLRES SIMALUNGUN adalah sebagai berikut:

1. Faktor Ekonomi

Salah satu penyebab terjadinya tindak pidana penyalahgunaan narkotika yang dilakukan oleh anak dibawah umur karena dilatarbelakangi oleh faktor ekonomi, dimana pelaku melakukan hal ini karena terdorong dan berkeinginan dari kebutuhan materi yang membuat seseorang ataupun pelaku tindak pidana untuk melakukan tindak pidana penyalahgunaan narkotika tersebut. Dimana di wilayah POLRES SIMALUNGUN sendiri penyalahgunaan narkotika yang dilakukan oleh anak dibawah umur terjadi disetiap tahunnya hal ini hasil dari wawancara penulis dengan Aiptu Ibrahim Sembiring, tindak pidana tersebut dilakukan oleh salah seorang pelaku bernama Risky Ananda dikarenakan terdorong oleh faktor ekonomi dimana pelaku rela menjadi kurir Shabu agar mendapatkan uang lebih untuk dapat bergaul dilingkungannya dan dapat memenuhi kebutuhannya sehari-hari.

2. Faktor Pendidikan

Faktor Pendidikan hasil wawancara dengan BRIPTU Samuel Purba salah SATu faktor penyebab terjadinya tindak pidana penyalahgunaan narkotika tersebut adalah dikarenakan kurangnya pengetahuan anak tentang aturan hukum khususnya dalam hal ini mengenai tindak pidana Narkotika. Hal ini disebabkan karena tingkat pendidikan dari pelaku tindak pidana Narkotika tersebut masih rendah, sehingga anak tersebut tidak mempertimbangkan akibat hukum atau sanksi hukum yang akan diterima pelaku apabila melakukan perbuatannya melakukan penyalahgunaan narkotika tesebut.

3. Faktor Pekerjaan

Faktor Pekerjaan Adapun salah SATu penyebab terjadinya tindak pidana penyalahgunaan narkotika dikarenakan dari faktor pekerjaan pelaku dimana pelaku tindak pidana yang sudah tidak sekolah harus bekerja agar dapat menghidupi dirinya sendiri sehingga melalukan pekerjaan menjual narkotika karena memiliki penghasilan yang besar dan proses pengerjaan yang dilakukan pun cepat tanpa memikirkan efek sampingnya.

4. Faktor Lingkungan dan Gaya Hidup

Faktor Lingkungan dan Gaya Hidup juga menjadi penyebab anak dapat melakukan penyalahgunaan narkotika. Anak yang terlalu bergaul bebas dan anak tersebut merasa agar dapat diterima oleh lingkungannya sehingga melakukan penyalahgunaan narkotika.

5. Faktor Keluarga

Faktor keluarga juga dapat mempengaruhi anak untuk melakukan penyalahgunaan narkotika karena hubungan antara Ayah dan Ibu yang tidak 
harmonis, dan komunikasi dalam keluarga yang kurang efektif antara orangtua dan anak dan kurangnya rasa hormat anak terhadap kedua orangtuanya.

6. Faktor Individu

Dalam perkembangannya, anak memiliki rasa ingin tahu yang sangat besar walaupun anak tersebut tidak berpikir panjang tentang apa akibat yang diterima nya saat sudah menyalahgunakan narkotika karena keinginannya yang sangat besar dan juga karena ingin mengikuti trend atau gaya di lingkungannya.

Masalah penyalahgunaan narkotika dikalangan anak dibawah umur yang dilakukan oleh Kepolisian Resort Simalungun akan terpecahkan apabila dilakukan upaya menanggulangi penyalahgunaan narkotika dengan cara melakukan upaya preventif dan upaya represif. Upaya preventif merupakan sebuah upaya yang dilakukan Kepolisian Resort Simalungun sebelum penyalahgunaan terjadi. Sementara itu upaya represif adalah suatu tindakan aktif yang dilakukan pihak Kepolisian resort Simalungun pada saat penyimpangan sosial telah terjadi.

Adapun penegakan hukum terhadap pelaku tindak pidana narkotika yang dilakukan oleh Kepolisian Resort Simalungun menunjukkan bukti keseriusan guna menanggulangi tindak pidana tersebut. Tercatat dari tahun 2018 s.d 2020 sebanyak 21 kasus tindak kejahatan yang berkaitan dengan narkotika dikalangan anak dibawah umur telah selesai di proses pada tingkat penyidikan. Tersangka dijerat dengan ketentuan yang tercantum di dalam Undang-Undang No 35 tahun 2009.

1. Upaya Preventif

Upaya Preventif adalah upaya yang dilakukan oleh pihak Polres Simalungun untuk mencegah terjadinya tindak pidana penyalahgunaan narkotika terhadap anak dibawah umur. Artinya upaya Preventif ini adalah mengutamakan upaya pencegahan daripada penindakan. Adapun upaya pencegahan tersebut sesuai hasil wawancara yang dilakukan bersama Bapak AIPTU Ibrahim Sembiring yaitu :

a. Kepolisian SAT Narkoba Simalungun melakukan Penyuluhan di sekolah, karang taruna dan gereja tentang bahaya penyalahgunaan narkotika bagi kesehatan dan mental anak atau melaksanan razia pada tempat keramaian.

b. Kepolisian SAT Narkoba melaksanakan tes urine secara gratis terhadap anak di wilayah Polres Simalungun dalam penyambutan hari ulangtahun Kepolisian.

c. Pihak Kepolisian akan memberikan hadiah kepada masyarakat sebagai pelapor tindak pidana penyalahgunaan narkotika yang dilakukan di wilayah Kepolisian Resort Simalungun.

d. Kepolisian SAT Narkoba Polres Simalungun Mengundang tokoh-tokoh adat, agama atau orang-orang yang berpengaruh di Kabupaten Simalungun untuk memberikan pemahaman serta pencerahan kepada masyarakat setempat tentang dampak penyalahgunaan narkotika.

\section{Upaya Represif}

Upaya Represif adalah upaya yang dilakukan oleh Kepolisian Resort Simalungun dalam rangka mengawasi peredaran Narkotika dikalangan anak dibawah umur agar tindak semakin meluas. Peranan penegak hukum salah SATunya mengaktualisasikan secara nyata, aturan-aturan hukum bisa terwujud dalam kaidah-kaidah sosial masyarakat. Sebagai suatu sarana untuk menegakkan hukum dengan penerapan sanksi pidana. Perumusan norma-norma pidana telah diatur dalam Undang-Undang No 35 tahun 2009, untuk menentukan kategori sanksi pidana lebih ditentukan oleh jenis-jenis penggolongan psikotropika dan narkotika yang dilanggar. Seyogyanya pemerintah mengatur tentang batas maksimal jumlah psikotropika dan narkotika yang disimpan, digunakan, dimiliki, secara tidak sah sehingga dapat membedakan pelaku tindak pidana, apakah digolongkan sebagai 
PATIK : JURNAL HUKUM Vol : 10 No. 1 April 2021, Hal 25 - 37

pemilik, pengguna atau pengedar. ${ }^{20}$ Adapun upaya penindakan tersebut sesuai hasil wawancara yang dilakukan secara bersama yaitu:

a. Jika bersih keras dan setelah diberikan pemahaman hukum bukti pedoman tentang bahayanya penyalahgunaan narkotika yang diberikan oleh Kepolisian SAT Narkoba Polres Simalungun tentang permasalah yang dihadapi yaitu maraknya penyalahgunaan narkotika yang dilakukan anak dibawah umur, maka permasalah tersebut diajukan proses sidik untuk diajukan di persidangan untuk mendapatkan tuntutan agar dapat memasukkan para pelaku tindak pidana penyalahgunaan narkotika ini kedalam Rehabilitasi sosial. Artinya mulai dari tahap penyidikan, penuntutan sampai adanya putusan akhir pengadilan para pelaku tindak pidana dimasukkan didalam rehabilitasi sosial. Ini dalam upaya agar para pelaku tidak melakukan tindak pidana itu lagi.

b. Melaksanakan kegiatan fisik, seperti patroli di daerah yang rawan tindak pidana penyalahgunaan narkotika tersebut secara rutin seperti daerah kecamatan Bandar wilayah hukum kepolisian sektor Bandar dan kecamatan Ujung Padang wilayah hukum Kepolisian sektor Ujung Padang.

c. Menghukum para pelaku dengan sebuah putusan tetap hakim sesuai Pasal 127 ayat 3 Undang-Undang No 35 tahun 2009 tentang Narkotika. Penanganan tindak pidana penyalahgunaan narkotika dengan upaya represif yang dilakukan oleh kepolisian Resort Simalungun serta Menindak pelaku kejahatan yang terbukti melakukan kejahatan sesuai dengan peraturan dengan sanksi yang bisa menimbulkan efek jera bagi pelakunya dan bisa menjadi ancaman bagi orang yang hendak melakukan hal yang sama sehingga mengurungkan niatnya.

Menanggapi pada permasalahan mengenai kendala yang dialami oleh Kepolisian, AIPTU Ibrahim Sembiring menyatakan pendapatnya dalam wawancara dengan penulis sebagai berikut: ${ }^{21}$ "jumlah personil yang terbatas memang masih merupakan hambatan terhadap Polres Simalungun, sehingga selama ini petugas yang menangani kasus-kasus narkotika memang harus ekstra kerja keras. Disamping itu masih terbatasnya sarana dan prasarana pendukung terutama untuk kecepatan pengungkapan kasus menjadi hambatan tersendiri."

Berdasarkan hasil wawancara diketahui bahwa hambatan yang terjadi secara internal adalah adanya keterbatasa sarana dan prasarana serta kesiapan sumber daya manusia yang cukup. Hal ini menunjukkan bahwa masih perlu adanya penambahan tenaga sumber daya manusia dengan kualifikasi kompetensi yang baik. Selain adanya penambahan tenaga sumber daya manusia Polres Simalungun juga memerlukan adanya penambahan sarana dan prasarana pendukung yang diperlukan penanggulangan narkotika.

Hambatan lain yang dihadapi Kepolisian Polresta Simalungun adalah informasi yang terputus. Seperti yang diungkapkan pada hasil wawancara penulis dengan narasumber berikut ini: 22 "kita dilapangan harus jeli untuk tahu siapa pengedar, pemakai dan perantara. Karena sangat sulit mendapatkan informasi mengenai penyalahgunaan narkotika.

${ }^{20}$ Bangonang,’Prosedur Penangkapan Terhadap Pelaku Tindak Pidana Narkotika yang Melarikan Diri Keluar Negeri menurut Hukum Pidana Internasional. Lex crimen,'Jurnal Hukum. Volume 2 Nomor (Juli, 2013)

${ }^{21}$ Hasil wawancara dengan Bapak AIPTU Ibrahim Sembiring, KAUR MINTU SAT NARKOBA POLRES SIMALUNGUN, pada tanggal 6 Agustus 2020, Pukul 11.00 wib.

${ }^{22}$ Hasil wawancara dengan Bapak AIPTU Ibrahim Sembiring,KAUR MINTU SAT NARKOBA POLRES SIMALUNGUN, pada tanggal 6 Agustus 2020, Pukul 11.00 wib. 
Kebanyakan kita peroleh informasi tersebut dari hasil lidik, kalau melaporkan jarang sekali pelapor."

Berdasarkan hasil wawancara diatas, penulis menyimpulkan bahwa minimnya laporan dari masyarakat menjadi hambatan tersendiri bagi kepolisian Polresta Simalungun untuk mengungkap terjadinya penyalahgunaan narkotika terutama dikalangan anak dibawah umur. Hal tersebut terjadi karena beberapa faktor seperti, sikap tidak mau tahu dengan apa yang terjadi di lingkungan sekitarnya, sesama penyalahguna narkotika, adanya indikasi ingin melindungi seseorang dari jeratan hukum.

Setiap kegiatan tidak selamanya berjalan dengan mulus. Hal ini desebabkan adanya keterbatasan manusia, termasuk upaya polisi dalam menanggulangi penyalahgunaan narkotika dikalangan anak dibawah umur. Pada penelitian sebelumnya juga terdapat kendala yang mengakibatkan terjadinya hambatan. Beberapa kendala tersebut diakui pihak SATuan Narkoba Polres Simalungun dan sangat menghambat kinerja mereka dalam pelaksanaan tugas dalam keseluruhan. Jumlah anggota yang masih kurang dari standart diakui menjadi hambatan dari dalam yang sering terjadi.

Adapun hambatan-hambatan dalam pelaksanaan upaya dalam menanggulangi tindak pidana penyalahgunaan narkotika yang dilakukan oleh anak dibawah umur yaitu:

1. Hambatan Upaya Preventif

Hambatan Upaya Preventif lebih mengutamakan pencegahan bukan penindakan yang dilakukan oleh SAT Narkoba dalam melakukan kegitan-kegiatan sosialisasi ataupun penyuluhan khususnya penyalahgunaan narkotika untuk mencegah terjadinya tindak pidana penyalahgunaan narkotika di Kabupaten Simalungun, hambatan yang yang di hadapi oleh personil SAT Narkoba adalah:

a. Kurangnya Kesadaran Masyarakat

Kurangnya kesadaran masyarakat ataupun respon dari masyarakat untuk melaporkan apabila terjadinya penylahgunaan narkotika dilingkungan tempat tinggal kepada SAT Narkoba yang sudah melakukan kegiatan penyuluhan dan sosialisasi dalam pemahaman hukum tentang bahaya penyalahgunaan narkotika .

b. Kurangnya Partisipasi Perangkat Daerah Setempat

Di dalam melakukan melakukan penyuluhan dan sosialisasi di daerah yang di tuju oleh SAT Narkoba, kurangnya partsipasi perangkat daerah dalam menyediakan sarana dan prasarana untuk kegiatan tersebut, seperti tempat,bangku dan kebutuhan lain yan mendukung kegiatan penyuuhan dan sosialisasi tersebut dan juga perangkat daerah seperti kecamatan terlambat memberikan informasi mengenai sosialisasi atau penyuluhan tentang pemahaman hukum serta penyalahgunaan narkotika.

2. Hambatan Upaya Represif

Hambatan Upaya Represif merupakan salah upaya tahapan terakhir yaitu dalam bentuk tindakan. Dalam hal melaksanakan penanganan laporan polisi, tindakan yang dilakukan oleh SAT Narkoba untuk seseorang yang melakukan tindak pidana penyalahgunaan narkotika untuk melanjutkan ke tahap rehabilitasi sosial, SAT Narkoba sering mengalami hambatan dalam melaksanakan tindakan tersebut.

Hambatan yang dialam oleh SAT Narkoba dalam melakukan tindakan Hukum sebagai berikut:

a. Polres Simalungun belum mampu membangun kesadaran masyarakat untuk melaporkan adanya tindak pidana penyalahgunaan narkotika.

b. Polres Simalungun kesulitan melacak pelaku jaringan pemasok narkotika di Wilayah Kepolisian Resort Simalungun 


\section{Kesimpulan Dan Saran}

Upaya Kepolisian dalam menanggulangi penyalahgunaan narkotika yang dilakukan oleh anak dibawah umur di wilayah Kepolisian Resort Simalungun dengan melakukan upaya preventif dan represif yaitu Upaya Preventif yang dilakukan oleh pihak Polres Simalungun untuk mencegah terjadinya tindak pidana penyalahgunaan narkotika dengan mengutamakan upaya pencegahan daripada penindakan. Yaitu dengan melakukan penyuluhan ke sekolah, karang taruna dan gereja tentang bahaya penyalahgunaan narkotika bagi kesehatan dan mental anak atau melaksanakan razia pada keramaian, dan Upaya Represif yang dilakukan Kepolisian Resort Simalungun dalam rangka mengawasi peredaran Narkotika dikalangan anak dibawah umur agar tidak semakin meluas. Pemberian pembinaan kepada anak di bawah umur dilakukan oleh Kepolisian Resort Simalungun dilakukan lebih rutin lagi.

Hambatan yang dihadapi oleh Kepolisian dalam menanggulangi penyalahgunaan narkotika adalah:Kurangnya kesadaran masyarakat ataupun respon dari masyarakat untuk melaporkan apabila terjadi penyalahgunaan, Kurangnya partisipasi perangkat daerah setempat, Polres Simalungun belum mampu membangun kesadaran masyarakat untuk melaporkan adanya penyalahgunaan narkotika dan Polres Simalungun kesulitan melacak jaringan pemasok Narkotika di wilayah Resort Simalungun. Anak yang ditangkap dan ditetapkan sebagai pelaku penyalahgunaan narkotika sebaiknya dilakukan pembinaan mental di rehabilitasi bukan di penjara karena dapat mempengaruhi mental anak itu sendiri.

\section{DAFTAR PUSTAKA}

\section{Buku dan Jurnal}

Andi Hamzah, Kejahatan Narkotika Dan Psikotropika, Sinar Grafika, Jakarta, 2018. Angger Sigit Pramukti, Sistem Peradilan Pidana Anak, Medpress, Yogyakarta, 2014.

A.W., Widjaya, Masalah Kenakalan Remaja dan Penyalahgunaan Narkotika, Armico , Bandung, 1985.

B. Bosu, Sendi-sendi Kriminologi, Usaha Nasional, Surabaya,1982.

C.S.T. Kansil, Buku Saku Hukum (hukum untuk tiap orang), Erlangga , Jakarta, 1986.

Gatot Supramono, Hukum Narkotika Indonesia, Djambatan , Jakarta ,2001.

Gatot Supramono, Hukum Narkotika Indonesia, : Djambatan, Jakarta, 2009.

Harsja W.Backtiar, Ilmu Kepolisian, Peguruan Tinggi Ilmu Kepolisian (PTIK) dan Gramedia, Jakarta, 1993.

Hasibuan, Pondang, Sahat Benny Risman Girsang, Erni Juniria Harefa, Janpatar Simamora, and Herlina Manullang. 2020. "AKIBAT HUKUM PENCABUTAN BERITA ACARA PEMERIKSAAN SAKSI DI DEPAN PERSIDANGAN DALAM TINDAK PIDANA NARKOTIKA (Studi Putusan Nomor 201/Pid.Sus/2018/PN Simalungun)". Nommensen Journal of Legal Opinion 1 (01):129-38. https://doi.org/10.51622/njlo.v1i01.341.

H.Pudi Rahardi, Hukum Kepolisian, Laksbang Mediatama, Surabaya, 2007.

H.R. Abdulssalam, Hukum Kepolisian, PTIK Press, Jakarta, 2011.

Maidin, Perlindungan Hukum Terhadap Anak Dalam Sistem Peradilan Anak Di Indonesia,

PT. Refika Aditama, Bandung, 2014.

Maidin Gultom, Perlindungan Hukum terhadap Anak dan Perempuan, PT Refika

Aditama, Medan, 2012. 
Marlina, Peradilan Pidana Anak di Indonesia Pengembangan Konsep Diversi dan Restorative Justice, PT Refika Aditama, Medan , 2009.

Moeljatno, Pokok-Pokok Hukum PenitensierIndonesia, Alfabeta, Bandung, 2010.

Moh.Taufik Makaro, S.H., M.H. Tindak Pidana Narkotika, Ghalia Indonesia, Jakarta,2019.

Muladi, Demokratisasi, Hak Asasi Manusia dan Reformasi Hukum di Indonesia, The Habibie Center, Jakarta, 2002.

Nashariana, Perlindungan Hukum Pidana Bagi Anak Di Indonesia, Rajawali Pers, Jakarta, 2018.

Rachman Hermawan S, Penyalahgunaan Narkotika Oleh Para Remaja, Eresco , Bandung, 1988.

R.Wiyono, Sistem Peradilan Pidana Anak Di Indonesia, Sinar Grafika, Ngunut, 2015.

Sihotang, L., \& Butar-butar, G. (2021). ANALISIS PINALTI HUKUM MATI KEPADA PERANTARA JUAL BELI NARKOTIKA DAN PEMBELIAN KATEGORI TANAMAN NARKOTIKA (STUDI KASUS NO. 1991/PID.SUS/2019/PN MDN). Nommensen Journal of Legal Opinion, 2(01), 24-36. https://doi.org/10.51622/njlo.v2i01.205

Soedjono Dirjosisworo, Hukum Narkotika di Indonesia, PT.Citra Aditya Bakti, Bandung, 1990.

Sudarsono, Kenakalan Remaja, PT. Rineka Cipta, Jakarta, 2018.

Sumarno Ma'asum, Penanggulangan Bahaya Narkotika dan Ketergantungan Obat, CV. Mas Agung, Jakarta, 1987.

Ubaedillah dan Abdul Rozak, Pancasila, Demokrasi, HAM dan Masyarakat Madanii, Kencana, Jakarta, 2012.

Wagiati Soetedjo dan Melani, Hukum Pidana Anak, Refika Aditama, Bandung, 2013.

Warsito Hadi Utomo, Hukum Kepolisian di Indonesia, Prestasi Pustaka Publisher, Jakarta, 2005.

\section{Internet}

https://www.kompasiana.com/dinsar01/55298840f17e617001d623af/korupsi-dan-narkobasebagai-extra-ordinary-crime, Pada 06 Juli 2020 Pukul 15:18 WIB https://www.hukumonline.com/klinik/detail/ulasan/lt53f55d0f46878/hal-hal-pentingyang-diatur-dalam-uu-sistem-peradilan-pidana-anak, Pada 31 Agustus 2020 Pukul 20:00 WIB 